American University Washington College of Law

Digital Commons @ American University Washington College of

Law

Articles in Law Reviews \& Other Academic Journals

Scholarship \& Research

2019

Why Central Banks Need to Take Human Rights More Seriously

Daniel D. Bradlow

Follow this and additional works at: https://digitalcommons.wcl.american.edu/facsch_lawrev

Part of the Banking and Finance Law Commons, Environmental Law Commons, Human Rights Law Commons, and the Law and Economics Commons 


\section{Why Central Banks Need to Take Human Rights More Seriously ${ }^{1}$}

Daniel Bradlow ${ }^{2}$

Most central bankers think that there is a tenuous connection between the operations of central banks and human rights. They think that this is not a problem because, as unelected officials, it would be inappropriate for them to take policy decisions that require political judgements. Their responsibility is to concentrate on the relatively narrow set of macroeconomic variables that are relevant to their mandates and to leave to their country's political leadership the decisions dealing with the complex and politically sensitive variables that affect the functioning of the economy and society. Moreover, they contend that they do not need to make such decisions. Their mandates require them to make decisions that must be implemented within time horizons that are too short to incorporate the relatively slow pace of the social changes that lead to sustainable human rights progress. They may add that if they do their job effectively they will help create a macro-economic environment that can facilitate the realization of human rights over time.

This position is no longer tenable. Climate change is forcing the central banking community to rethink their view of their responsibilities. The recent release of the Network for Greening the Financial System's first comprehensive report on climate change as a source of financial risk $^{3}$, is the latest indication that central banks are beginning to take environmental risks more seriously in their monetary and financial operations. They can no longer treat the environment as fixed, in the sense that it is changing too slowly to affect current monetary and financial policy.

Their focus on climate change is inevitably pushing central banks to start paying more attention to other environmental risks and to social considerations more generally. For example, in order to fully understand the risk that climate poses to price and financial stability over the relevant time horizon, they will have to consider not only the risk of an extreme weather event but how changing weather patterns will affect such variables as food production, migration patterns, social stability and how these, in turn, will influence demand in the economy, credit allocation, inflation, government deficits and people's access to food, water, housing, jobs and social security.

In other words, central bankers are being inexorably pushed to consider the relationship between central banking and human rights, particularly economic and social rights. This article briefly describes this relationship and its implications for central banks. It makes two points in this regard. First, central banks have human rights responsibilities. Second, both their monetary and financial operations have unavoidable human rights impacts which need to be incorporated into their decision making and governance procedures. In order to make these points the paper is divided into three parts. The first part discusses the human rights

\footnotetext{
${ }^{1}$ ALL RIGHTS RESERVED. DO NOT QUOTE OR DISTRIBUTE WITHOUT PERMISSION OF AUTHOR

${ }^{2}$ SARCHI Professor of International Development Law and African Economic Relations and Emeritus Professor of Law, American University Washington College of Law. Email: danny.bradlow@up.ac.za

3 "A Call for Action: Climate Change as a Source of Financial Risk", First Comprehensive Report, Network for Greening the Financial System (April 2019). At the time the report was issued, the NGFS was a network 18 Central Banks and Supervisors and 5 international organizations. When it was established in 2017 it consisted of 8 central banks and supervisors.
} 
responsibilities of central banks. The second part discusses how they should deal with their human rights responsibilities. The third part is a conclusion.

\section{The Connections Between Central Banks and Human Rights}

Central banks are created by law in their home states. ${ }^{4}$ It determines their mandates, powers, and governance arrangements. They also must operate in compliance with all the applicable law including the constitutional and international legal obligations of their home state. Thus, in principle, central banks must take the international human rights commitments of their sovereign into account in the way in which they implement their mandates and conduct their operations.

While the precise mandates of central banks vary, all central banks are responsible for maintaining price stability. Their primary policy tools for achieving this objective are interest rates, the capital and reserve requirements for banks, and trading debt instruments in financial markets. In the past, central banks have used other policy tools to maintain stable prices, such as the quantity of money in the economy or a fixed standard, such as the gold standard.

Central banks also act as a lender of last resort to the banking system or more generally to the financial sector, regulate and supervise the activities of banks and other financial institutions, manage the country's payment system, maintain financial stability and manage the foreign reserves of the country. In some countries, the central bank may be assigned additional responsibilities such as promoting development finance or financial inclusion.

Many, but not all central banks operate independently of their political leadership. ${ }^{5}$ It is important to note that usually their independence is limited to instrument independence. This means that the central bank does not sets its own monetary policy objectives but determines for itself how it will use its policy tools to meet this goal. For example, the political leadership determines that inflation should be maintained within a specified range over a certain period of time and then lets the central bank decide how to use its policy tools to maintain inflation within this target zone. ${ }^{6}$

This arrangement has two consequences. First, it means that the central bank's independence is ostensibly limited to the technical issues regarding the best way to reach the goals that the government has set. Second, since the political leadership sets the goal, it is assumed, at least implicitly, that the social, environmental and political implications of the country's monetary and financial policies are its responsibility and not that of the central bank. Thus, the central bank is not assumed to be publicly accountable for the social or environmental impacts of its decisions. This assumption is strengthened by the relatively short time horizons (about 18-36 months) which central banks use in their monetary operations.

\footnotetext{
${ }^{4}$ The major exception to this general rule is the European Central Bank. It was created by Articles 127-133, 282-4 of the Treaty on the Functioning of the European Union available at: https://www.ecb.europa.eu/ecb/legal/pdf/oj_c 2016 202 full_en txt.pdf

${ }^{5}$ For example, the People's Bank of China is not independent and operates under the leadership of the State Council. See, "About the PBC" People's Bank of China website, available at:

http://www.pbc.gov.cn/english/130712/index.html

${ }^{6}$ One prominent exception is the US Federal Reserve. Section 2A of the Federal Reserve Act stipulates that the Federal Reserve is responsible for maximizing employment, stabilizing prices and moderating long term interest rates. It can decide for itself how it should interpret and implement this broad mandate. The Federal Reserve Act is available at: https://www.ohchr.org/documents/publications/GuidingprinciplesBusinesshr_eN.pdf
} 
However, in reality central banking is not a purely technical function. As indicated above, a central bank's operational decisions will have environmental and social as well as monetary or financial implications within the time period used by the central bank in its decisionmaking. For example, the social and environmental impacts, but not necessarily the monetary impacts, of its decision to change interest rates will vary depending on how it implements the decision. If the central bank decides to change the rates by trading in financial instruments the social and environmental impacts will be determined by which instruments it chooses to trade and in what proportions, and by the size and the timing of these transactions. ${ }^{7}$ On the other hand, the central bank could cause a different set of social and environmental impacts if it chose to implement the decision by changing the reserve requirements for banks or the interest rate it charges banks for short term loans. In these cases, the social and environmental impacts will depend on how the banks change their credit allocation decisions in response to the central bank's action.

This means that the central bank's operational decisions can affect the risk and reward calculations of financial institutions so that they allocate more or less of their resources, for example, to government financing, green technologies, carbon intensive businesses, luxury apartments, low income housing, small and medium size businesses or multinational corporations. Similarly, their decisions regarding the factors that can affect financial stability and the way in which they exercise their lender of last resort responsibilities will have social and environmental impacts. For example, central banks could be under-estimating financial risks if they fail to incorporate such things as the impact of climate change on the availability of food and water and on migration patterns into their decisions regarding the risks to financial stability. ${ }^{8}$ In this regard, it is noteworthy that some central banks, for example those of China, England and the Netherlands, have begun to incorporate environmental risks into their financial stability assessments. Similarly, the central banks of Kenya, the Netherlands and the Federal Reserve Bank of San Francisco consider such factors as community development and financial inclusion in their stewardship of their financial systems. The Dutch central bank, in fact, now has a mandate to include sustainability in its decision making and the Chinese central bank has been authorized to take climate considerations into account in its monetary decisions.

The fact that the operations of central banks inevitably have social impacts means that they cannot avoid having an impact on the social and economic rights of the citizens of their countries. This means that their decisions to change interest rates and how they are implemented, to support/not support banks in distress, and how much risk to tolerate in the financial system can affect the access of some people in the society to housing, healthcare, education, work and to adequate food and water. It may also have implications for the security of their pensions and for the quality of their environments.

\footnotetext{
${ }^{7}$ For example, in its open market operations to implement interest rate decisions, the US Federal Reserve, pursuant to Section 14 of the Federal Reserve Act, $i d$, can trade, inter alia, Treasury securities, and securities of any agency of the United States. The South African Reserve Bank is authorized to trade in treasury bills, and any government debt issued for any commercial, industrial or agricultural purpose or by a local authority. See Section 10(g), South African Reserve Bank Act, available at: https://www.resbank.co.za/AboutUs/Legislation/Documents/SARB\%20Act/1)\%20\%20South\%20African\%20R eserve\%20Bank\%20Act,\%201989\%20(Act\%20No.\%2090\%20of\%201989).pdf

${ }^{8}$ The information in this paragraph is taken from D. Schoenmaker, "Greening Monetary Policy", Breugel Working Paper Issue\# 02 (19 February 2019); "A Call for Action: Climate Change as a Source of Financial Risk”, First Comprehensive Report, Network for Greening the Financial System (April 2019)
} 


\section{The Human Rights Responsibilities of Central Banks}

The unavoidable impact of central banking operations on human rights means that central banks have to develop a better understanding of their human rights responsibilities and its implications for their decision making and operations. The applicable law is the starting point for this analysis. However, while the relevant law and jurisprudence may define the human rights obligations of the state in some detail, it is unlikely to provide detailed guidance on how the central bank in that state should operationalize these requirements. Thus, the central bank will have to determine for itself how to do this.

A good reference tool in this regard is the UN Guiding Principles on Business and Human Rights. ${ }^{9}$ These principles stipulate that all businesses should have a human rights policy and should conduct adequate human rights due diligence before and during their decision making and implementation process. The former requirement is usually interpreted to mean that the senior leadership of the entity should adopt a human rights policy that is publicly available and that should be applied in the operations and decision-making of the entity. The latter requirement means that they should conduct human rights impact assessments of their proposed operations. They should also then take steps to avoid or mitigate all adverse human rights impacts.

It is important to note that central banks will face particular challenges in meeting their human rights responsibilities. Since they are public institutions, whatever human rights policy they adopt may have implications for other state owned entities and for the political leadership in the country. This however, will complicate but not render impossible the task of drafting a central bank human rights policy. The drafters will need to ensure that the policy is respectful of the central bank's independence, monetary and financial mandates and its human rights responsibilities while not contradicting the human rights policies of their home state in general and other parts of the government involved in economic policy making in particular. This suggests that there needs to be some dialogue between central banks and the political authorities about the implications of the central bank's proposed human rights policy.

Central banks will also experience unique challenges in conducting human rights impact assessments. For example, in regard to their monetary policy, the central bank's ability to conduct detailed human rights impact assessments is complicated by the relative speed and discretion with which they must operate. This does not however make it impossible to assess human rights impacts. Instead, it suggests that central banks need to develop and maintain a sufficiently detailed general understanding of their actual human rights impacts so that they can make informed judgements about the likely impacts of their proposed monetary decisions. A similar approach should be taken towards all the other functions performed by the central bank. This means that the human rights impacts of each of these functions should be analyzed to more fully understand both their positive and negative human rights impacts.

\footnotetext{
${ }^{9}$ Available at: https://www.ohchr.org/documents/publications/GuidingprinciplesBusinesshr eN.pdf. The UN Human Rights Council endorsed these principles in its resolution 17/4 of 16 June 2011. Another useful reference too is the Guiding Principles on Human Rights Impact Assessments of Economic Reforms, that were prepared by the Independent Expert on the Effects of Foreign Debt and Other Related International Financial Obligations of States on the Full Enjoyment of Human Rights, particularly Economic, Social and Cultural Rights and submitted to the UN Human Rights Council, Document A/HRC/40/57 (25-February-22March 2019) available at: https://documents-dds-ny.un.org/doc/UNDOC/GEN/G18/443/52/PDF/G1844352.pdf?OpenElement
} 
One consequence of these assessments is likely to be that it will push central banks to assess if their current decision making and operational procedures and practices are appropriately designed to identify, assess and, if necessary respond to these impacts. This analysis can be updated periodically to ensure that central bank decision makers are fully informed about the human rights impacts of their proposed decisions.

In this regard, it is important to note that a human rights impact assessment can provide the central bank with an important and novel benefit. This follows from the fact that the human rights impact assessment focuses on the impact of central bank operations on individuals and communities. This disaggregated approach offers central banks a more detailed and nuanced understanding of how its policies actually affect different sub-groups of their society and thus of the true costs and benefits of their policies and actions.

Second, acknowledging their human rights responsibilities means that the central banks are also recognizing that their unelected leaders in fact are making decisions that affect the rights of citizens. Although this reality is unavoidable, it does raise questions about the governance and independence of central banks. It is important to note that this does not mean that central banks should lose their independence. The reason is that there are monetary benefits associated with having an independent central bank that need to be protected. In addition, there are costs that would be associated with allowing the political leadership to use the central bank's increased attention to human rights to undermine the central bank's instrument independence.

This suggests that there will need to be a re-evaluation of how central bank independence can be protected while striking the optimal balance between the central bank's human rights and monetary and financial responsibilities. This will require creative thinking about alternate ways in which central banks can be held accountable for their compliance with their monetary, financial and human rights responsibilities. It may also require reassessing the central bank's appointment process for its policy makers and the appropriate level of stakeholder participation in this processes. In this regard, attention should also be paid to the implications of these changes for the optimal functioning of financial markets, financial institutions and the economy.

\section{Conclusion}

The above analysis demonstrates three key points. First, central banks cannot operate without having social impacts and thus without impacting human rights. Second, human rights offers central banks a new tool for understanding the true costs and benefits of their proposed actions as well as useful additional information that can help them identify ways to mitigate the adverse consequences of their action. Third, central banks can meet their human rights responsibilities without compromising the independence they need to effectively meet their monetary and financial responsibilities. 